\title{
Management Innovation and Its Measurement
}

\author{
Teresa Kraśnicka ${ }^{1}$, Wojciech Głód \\ and Martyna Wronka-Pośpiech ${ }^{3}$
}

\begin{abstract}
The aim of this paper is to explain the nature of management innovation, as well as to propose its measurement instrument. The paper offers a review of key publications on management innovation published in research journals within the last two decades. The critical analysis - primarily focused on definitions, the proposed dimensions of management innovation and the scales used for their measurement - has allowed for the development of an original tool for measuring management innovation (MI). Five dimensions of management innovation are proposed, namely, strategic dimension, structural dimension, employee motivation and development dimension, interorganisational relations and partnership dimension, and ICT dimension. Using survey data of 301 employees from different companies in Poland, the validation of the management innovation measurement instrument was conducted. Internal consistency analysis (Cronbach's alpha) and factor analysis, used to test the statistical reliability of the tool, yielded satisfactory results. The findings of this study contribute to advancing innovation research, particularly the state of knowledge on management innovation. Implications for both research and managerial practice are also presented. The proposed five-dimension management innovation model can be used to measure the scope of management innovation in further research and develop the knowledge about links between MI and an organisation's performance or its impact on technological innovativeness. In addition this study uncovers a wide range of information on management innovation issues for interested parties and for future research.
\end{abstract}

Keywords: innovation, management innovation, measurement.

\footnotetext{
1 Teresa Kraśnicka, Associate Professor, Department of Entrepreneurship and Management Innovation, University of Economics in Katowice, 1-go Maja 50, 40-287 Katowice, e-mail: tkrasnicka@gmail.com.

2 Wojciech Głód, Assistant Professor, Department of Entrepreneurship and Management Innovation, University of Economics in Katowice, 1-go Maja 50, 40-287 Katowice, e-mail: wojciech.glod@ue.katowice.pl.

3 Martyna Wronka-Pośpiech, Assistant Professor, Department of Entrepreneurship and Management Innovation, University of Economics in Katowice, 1-go Maja 50, 40-287 Katowice, e-mail: martyna@ue.katowice.pl.
} 


\section{INTRODUCTION}

Nowadays, it is recognized that the success of an organisation and its survival, in particular a knowledge-based one, depend on creativity, innovation, and inventiveness (Martins \& Terblanche, 2003). Accordingly, innovation has become the key goal of many organisations because of its potentially significant impact on organisational performance (Lee, 2008). This recognition embraces not only technological innovations, but also non-technological - organisational, marketing (Oslo Manual, 2005) and, finally, management innovations (Hamel, 2006). Management innovation is one particular type of innovation (Damanpour \& Aravind, 2011), and refers to the development and implementation of new managerial practices, processes or structures (Birkinshaw, Hamel \& Mol, 2008). In contrast to technological innovation, management innovation (MI) affects the "social" rather than the physical technologies of a firm (Nelson \& Sampat, 2001).

Although in recent years a number of publications on management innovation have been released, the observation made in 2006, that "despite its importance, management innovation remains poorly managed and poorly understood", is still relevant (Birkinshaw \& Mol, 2006). One reason may be scarce scientific research that would not only account for the emergence of management innovations, but above all confirm their significance for and impact on technological innovations and a firm's financial performance. Research should focus on the role of top management who probably do not have a direct influence on technological innovations (Elenkov \& Manev, 2005), but they contribute to an organisation's increased innovativeness through the development of new solutions in management.

Management innovation consists of changing a firm's organisational form, practices and processes in a way that is new to the firm and/or industry and results in leveraging the firm's technological knowledge base and its performance in terms of innovation, productivity and competitiveness (Volberda, Van Den Bosch \& Heij, 2013). The issue of conceptualizing and operationalising management innovation is not concluded.

Therefore, a number of reasons encourage research into $\mathrm{Ml}$, in particular the attempts at its operationalisation and the development of a measurement tool. This paper aims to fill the gap in the existing innovation theories by creating a multidimensional approach to innovation in the area of enterprise management and proposing its dimensions, which will allow for the development of a management innovation measurement tool. This will offer an opportunity to study management innovation and its impact on the performance of enterprises in a transition economy, such as Poland. 


\section{LITERATURE REVIEW}

\section{Innovation and innovativeness in an organization}

Innovations are perceived to be an important factor affecting an organisation's performance and its competitive position as well as a stimulus to economic growth. As a result, innovation has become a priority not only for corporate executives, but also for state governments and the European Union (Mothe \& Thi, 2010). The significance of innovation for economic development was already recognised by Schumpeter. Although he had a comprehensive understanding of innovation and did not limit it to new products, for many years attention has been mainly focused on product or technological innovations, as highlighted by many researchers (Birkinshaw et al., 2008; Damanpour \& Aravind, 2011). This has changed, however, and now most innovation researchers define innovation as the implementation of meaningful changes in an organisation, which improve not only products/ services and technological or administrative processes, but also business procedures, programmes and models, which create new value for an organisation's stakeholders (Timmerman, 2009). Relatively recently, other forms of innovation, often referred to as organisational (Rahimi, Damirchi \& Seyyedi, 2011), non-technological (Mothe \& Thi, 2010) or soft innovation (Sundbo, Gallina, Serin \& Davis, 2006), have also been recognised. The confirmation that the definition of innovation has been expanded can be found in modern definitions of innovation (Crossan \& Apaydin, 2010, Adams, Bessant \& Phelps, 2006) and its numerous typologies (Oslo Manual 2005, Mayle (ed.), 2006; Sundbo et al., 2006; Wickham, 2006).

Accordingly, innovativeness as a capability to generate, adapt and implement innovation (Garcia \& Calantone, 2002) embraces not only technological (product and process) innovation, but also non-technological innovation understood commonly as organisational innovation and, increasingly more often, innovation in management (Mothe \& Thi, 2010). The definition of innovation in management emphasises its comprehensive meaning, including management innovation. Moreover, some researchers argue that the old paradigm of industrial innovation, with technological innovation at its core, will be replaced by the new paradigm of innovation research, recognizing the importance of non-technological innovation (Volberda et al., 2013). Management innovation includes new solutions implemented in the management process, methods or structure. It is essentially the manifestation of the innovativeness of top management, i.e. their ability to generate, adapt and implement new solutions in an organisation's management. 
Definitions of management innovation and their role in organizations Our literature review concerning the interpretation of the management innovation concepts is based on the three-step approach developed by Tranfield, Denyer and Smart (2003): planning, execution, and reporting. Therefore, our methodology is that of a systematic review, the aim of which is a conceptual consolidation across a fragmented field. It uses systematic data collection procedures, descriptive and qualitative data analysis techniques, and theoretically grounded synthesis. Based on the adopted methodology, we compiled the definitions of management innovation presented in literature from 1994 in Table 1. It must be stressed, however, that the notion of management innovation itself and innovation in management under different terms appeared in literature much earlier. Our literature review confirms that:

- MI was studied under different terms (organisational, administrative) (Damanpour \& Aravind, 2011; Meuer, 2013) in the past and continues to be included in other research areas, e.g. as organisational innovation (Crossan \& Apaydin, 2010);

- MI definitions according to different authors seem to draw on a commonly accepted definition from Birkinshaw, Hamel and Mol (2008); according to these authors, management innovation means the invention and implementation of a novel management practice, process, structure, or technique; such innovations should aim to improve a firm's performance (Vaccaro, Jansen, Van Den Bosch \& Volberda, 2012; Mothe \& Thi, 2010);

- Mls are meaningfully new solutions, i.e. they have not been implemented in a particular enterprise; they can be adapted (e.g. management methods already in use in other organisations) or developed exclusively to meet the needs of a given organisation;

- attempts are undertaken to combine the two approaches - one proposed by Birkinshaw, Hamel and Mol (2008) and the other developed by the European Commission (Innobarometer, 2009), included in the third edition of the Oslo Manual (2005); this point of view is represented by Hecker and Ganter (2013), who argue that both these conceptions can be considered consistent. 
Table 1. Compilation of chosen definitions of management innovation (published 1994-2014)

\section{Original definition of management innovation}

Pervasive and embracing process which includes research, development, and implementation of new ideas and behaviours.

Innovation that leads to new administrative procedures, policies, and organisational structures.

Embodying the adoption of administrative programs, processes, or techniques new to the adopting organisation.

New ways to organise business activities such as production or $R \& D$, and innovations that have to do with the organisation of human resources.

Multifaceted concept that admits different interpretations and terms, such as innovation or innovative behaviour in organisations, new combinations.

The implementation of a new organisational method in the firm's business practices, workplace organisation or external relations. (...) The distinguishing features of an organisation innovation compared to other organisational changes in a firm are the implementation of an organisational method (in business practices, workplace organisation or external relations) that has not been used before in the firm and is the result of strategic decisions taken by management.

Innovations that refer to disembodied technology such as unpatented know-how, property rights, and management and organisation. They are new, novel organisational entities, which can be an industry structure, a firm's structure, a production form or process, or an institution in general.

Innovation that relates to changes in how managers set directions, make decisions, coordinate activities, and motivate people.

A marked departure from traditional management principles, processes, and practices or a departure from customary organisational forms that significantly alters the way the work of management is performed.

MI refers to an organisation adopting new technologies, new ideas and processes to change or implement in a managerial section such as computer based administrative innovations or new employee reward/training schemes.

The generation and implementation of a management practice, $\mathrm{Ml}$ process, structure, or technique that is new to the state of the art and is intended to further organisational goals.

Innovations that are related to management activities and are connected with the organisation's social system.
Source innova-

tion

Ol

Damanpour

(1996)

$\mathrm{Al}$

Gosselin

(1997)

$\mathrm{Al}$

Ravichandran (2000)

Ol

Edquist, Hommen \& McKeIvey (2001)

MI

Lam (2005)

OI

Oslo Manual (2005)

OI Sanidas (2005)

MI

Hamel (2006)

MI

Vijande \&

Gonzalez

(2007)

Birkinshaw et al. (2008)

Al

Tanninen, Jantunen \& Saksa (2008) 


\section{Original definition of management innovation}

Type of Source
innova-
tion

New or significantly improved organisational structures (e.g. knowledge management, workplace organisation or external relations).

$\mathrm{MI}$

DG Enterprise and Industry

Administrative innovations are indirectly related to the basic work Al activity and more directly related to its managerial aspects such as organisational structure, administrative process, and human resources.

Implementation of a management practice, process, or structure $\mathrm{MI}$ that is new to the adopting organisation. New practices,

Crossan \& Apaydin

Vaccaro et al. (2012) processes, and structures that change the nature of managerial work at the firm level.

New approaches to devise a strategy and structure in the organisation, modify the organisation's management processes, and motivate and reward its employees.

Innovation that reflects a functionally flexible division of labour. Within this definition, an example of organisational innovation in the workplace is the implementation of activities that increase employees' autonomy in decision-making.

$\mathrm{Ml}$ assumes that key individuals within organisations deliberately $\mathrm{MI}$ introduce new practices, processes, or structures, in order to improve the organisation's performance.

MI refers to innovation in management systems, knowledge management, and supporting activities.

Walker, Damanpour \& Devece (2011) Cavagnoli (2011)

Vaccaro et al. (2012)

Organizational innovation is a new or significantly improved knowledge management system intended to better use or exchange information, knowledge and skills within the enterprise, implement a major change to the organization of work, i.e. changes in management structure or integrating different departments or activities, or implement a new or significant change in relations with other firms or public institutions, i.e. through alliances, partnerships, outsourcing or subcontracting.

The introduction of new management practices is a form of MI. MI This form of MI implies a change in organisation, and thus a degree of evolution.

Kraus, Pohjola \& Koponen (2012)

OI Gallego, Rubalcaba \& Hipp (2012)

Change in the firm's organizational and management practices that marks a significant departure from the status quo organisational change that is new (at least to the firm), intended

Perello-Marin, Marin-Garcia \& Marcos-Cuevas (2013) to further organisational goals, and the result of strategic decision Hecker \& Ganter (2013) making.

Key: Al - administrative innovation, $\mathrm{Ml}$ - management innovation, Ol - organisational innovation.

Innovations in the area of management may be one of the key factors affecting the performance and development of modern organizations, 
operating in a turbulent environment. In the new era of innovation, when, characteristically, firms co-create new solutions with consumers and acquire resources from the outside (Prahalad \& Krishnan, 2010), innovation management will become one of the necessary conditions for the survival of firms or an improvement in their market position, as it shapes a firm's innovation orientation (Wood, 2007; Dobni, 2010) and, consequently, allows for its implementation by developing new structural solutions and designing organisational processes and human resources management systems (AhnSook, 2004), as well as looking for resources outside an organisation. We are convinced that the role of management innovation will gain in importance in the knowledge-based economy which, in the increasingly difficult conditions of globalised economies, will require firms to seek entirely new sources of competitive advantage. This involves an ability to find new business models, develop networks (also with consumers) or use new communication tools, which are perceived as an organisation's new competencies (Kraus et al., 2012). In a constantly changing environment organisations need to develop new competencies, such as adaptability, a capability to integrate and reconfigure internal and external skills and resources, referred to as dynamic competencies (Eisenhardt \& Martin, 2000). Many scholars emphasise that under global competition management innovation may contribute to building sustained competitive advantage, as it is more difficult to replicate (Volberda et al., 2013). In the resource-based view, sustained competitive advantage stems from valuable, rare, inimitable and non-substitutable resources.

\section{Innovations in the area of management - three trends}

The literature review, including the definitions in Table 1, indicates that management innovation as a new management practice, process, structure, or technique (Birkinshaw et al., 2008) is not always labelled as MI. This is confirmed by Damanpour and Aravind (2011), who describe all three approaches accounting for innovation in the area of management (organisational innovation, administrative innovation and management innovation) and they use the term "managerial innovation".

Originally, the term "organisational innovation" was used mainly by economists in order to differentiate it from technological innovation, but it also appeared in the area of management studies (Williamson, 1975; Chandler, 1962). Chandler (1962), for example, distinguished between new products and processes from a firm's new organisational structures. Edquist, Hommen and McKelvey (2001) defined organisational innovation as new ways of organizing business activity such as production or R\&D, which affect the coordination of human resources. Organisational innovation defined this 
way embraces, first of all, changes in organisational structures or procedures, facilitating change and growth of an organisation.

It should also be noted that the methodological findings of OECD specialists, acknowledged by many researchers (Gallego, Rubalcaba \& Hipp, 2012; Hecker \& Ganter, 2013; Camison \& Villar-Lopez, 2014), played an important role in defining organizational innovation and understanding its meaning. The fact that organisational innovation is identified as separate from technological innovation means that its role is recognized as not only a response to technological change, but as "a necessary pre-condition for technological innovation" (Lam, 2004), which to some extent is confirmed by research results (Camison \& Villar-Lopez, 2014).

At the same time, publications featured administrative innovation, which were set apart from product innovation and technological innovation, related to changes in products and production systems, implemented in order to meet the needs and expectations of customers. Administrative innovation was defined as oriented towards the effectiveness and efficiency of processes and systems used to manage an organisation (Damanpour \& Evan, 1984). Bantel and Jackson (1989) emphasize that it has a positive effect on how an organisation operates and a management decision-making process works.

It is only recently that the term "management innovation" has attracted significant interest amongst scholars. The critical date was probably 2005, when Birkinshaw, Hamel and Mol (2005) published an article on such innovations in the Advanced Institute of Management Working Papers. Hamel classifies management innovation as a departure from traditional management principles, processes and practices or a departure from solutions universally used in organisations, which has a considerable effect on how organisations operate (Hamel, 2006). In other words, management innovations are changes in how managers work.

The change in the approach to non-technological innovation and the recognition of the role played by innovation going beyond a wide scope of technological innovation (product and process innovation, primarily concerning manufacturing technologies) are clearly illustrated by the consecutive editions of the Oslo Manual. In the second edition (1997) organisational and non-technological innovation are already included in the annex, while the third edition includes marketing and organizational innovation as a distinct form of innovation in a firm (Oslo Manual, 2005).

\section{Dimensions of management innovation in literature}

Working on the operational definition of management innovation we encounter major difficulties. The most frequently quoted definition, 
proposed by Birkinshaw, Hamel and Mol (2008), can be a good example of operationalisation, presented by these scholars, who distinguished four elements (dimensions): management practices, management processes, organisational structures and techniques, reflecting different aspects of principles, rules and routines in an organisation. However, they admitted that the differences between practices, processes, structural aspects and techniques were neither conceptually nor empirically clear (2008). The precise definition of these terms (management practices, processes and methods/techniques) remains a serious challenge. Therefore, studies on management innovation and the empirical testing of developed models involve various ways of operationalisation, both in the management innovation approach (Walker et al., 2011; Birkinshaw et al., 2008) and when research deals with this type of innovation, but is conducted within a wider framework of organisational or non-technological innovation (Elenkov \& Manev, 2005; Mothe \& Thi, 2010). Selected examples of dimensions of management innovation and organisational innovation (including innovation in management) are presented in Table 2.

Table 2. Selected examples of dimensions of innovation in management - the last 10 years

\begin{tabular}{|c|c|c|c|c|}
\hline Author & Proposed dimension & MI & OI & EV \\
\hline $\begin{array}{l}\text { Wang \& } \\
\text { Ahmed } \\
(2004)\end{array}$ & $\begin{array}{l}\text { Innovativeness: } \\
\text { - strategic } \\
\text { - process } \\
\text { - behavioural } \\
\text { - market } \\
\text { - product }\end{array}$ & & $x$ & Yes \\
\hline $\begin{array}{l}\text { Elenkov \& } \\
\text { Manev (2005) }\end{array}$ & $\begin{array}{l}\text { - new human resources development programmes } \\
\text { - new planning systems } \\
\text { - new control systems } \\
\text { - created organisational units or positions } \\
\text { - new approaches to capital resources allocation } \\
\text { - new management information systems }\end{array}$ & & $x$ & Yes \\
\hline $\begin{array}{l}\text { Birkinshaw et } \\
\text { al. (2008) }\end{array}$ & $\begin{array}{l}\text { - management practices } \\
\text { - processes } \\
\text { - organisational structures } \\
\text { - management techniques }\end{array}$ & $x$ & & No \\
\hline $\begin{array}{l}\text { Mothe \& Thi } \\
\text { (2010) }\end{array}$ & $\begin{array}{l}\text { - management practices } \\
\text { - approaches to production organisation } \\
\text { - external relations }\end{array}$ & & $x$ & Yes \\
\hline $\begin{array}{l}\text { Terziovski } \\
\text { (2010) }\end{array}$ & $\begin{array}{l}\text { - innovation strategy } \\
\text { - formal structure } \\
\text { - customer and supplier relationships } \\
\text { - innovation culture } \\
\text { - technological capabilities }\end{array}$ & & $x$ & Yes \\
\hline
\end{tabular}




\begin{tabular}{|c|c|c|c|c|}
\hline Author & Proposed dimension & MI & OI & EV \\
\hline $\begin{array}{l}\text { Walker et al. } \\
\text { (2011) }\end{array}$ & $\begin{array}{l}\text { - IT technologies } \\
\text { - administrative dimension, embracing new management } \\
\text { systems and processes }\end{array}$ & $\mathrm{X}$ & & Yes \\
\hline $\begin{array}{l}\text { Damanpour } \\
\text { \& Aravind } \\
\text { (2011) }\end{array}$ & $\begin{array}{l}\text { Dimension pairs: } \\
\text { - strategy vs. structure } \\
\text { - innovations in forms and in procedures } \\
\text { - information technology and administrative dimension } \\
\text { - exploratory vs. exploitative innovations }\end{array}$ & $\mathrm{x}$ & & No \\
\hline $\begin{array}{l}\text { Vaccaro et al. } \\
(2012)\end{array}$ & $\begin{array}{l}\text { - management practices (setting new rules and ensuing } \\
\text { procedures) } \\
\text { - management processes (changes in routine) } \\
\text { - structures (communication methods, a scope of autonomy } \\
\text { and decision-making competencies) }\end{array}$ & $x$ & & Yes \\
\hline Hollen, Van & - setting objectives & $x$ & & No \\
\hline Den Bosch & - motivating employees & & & \\
\hline \& Volberda & $\begin{array}{l}\text { - coordination } \\
\text { - decision making }\end{array}$ & & & \\
\hline Hecker \& & - innovation in the firm' s workplace organization & $x$ & & Yes \\
\hline Ganter (2013) & $\begin{array}{l}\text { - innovation in the firm's knowledge management } \\
\text { - innovation in the firm's external relations }\end{array}$ & & & \\
\hline Camison \& & - organizational innovations in business practices & & $x$ & Yes \\
\hline Villar-Lopez & - innovations in workplace organization & & & \\
\hline$(2014)$ & - new organizational methods in external relations & & & \\
\hline
\end{tabular}

Key: $\mathrm{MI}$ - the concept is strictly related to management innovations; OI - the concept clearly embraces management innovations, which, however, belong to a wider category of organisational innovations; EV -empirical validation of the model developed by a particular author/team.

The review shows that in the last 10 years the subject has attracted a lot of interest from scholars, who unanimously indicate the necessity not only to recognize management innovation as separate from technological innovation, but also to continue research into this emerging field (Volberda et al., 2013). This, however, entails a number of problems, such as a methodological difficulty in reconciling the management innovation concept with the principles included in the Oslo Manual. Table 2 shows attempts made by some authors to combine these two approaches (Hecker \& Ganter, 2013). On the other hand, as Volberda, Van Den Bosch and Heij indicate (2013), most researchers tend to apply four dimensions proposed by Birkinshaw, Hamel and Mol (2008), while empirical studies are based on different operationalisations. This is confirmed by our English-language literature review, which has identified only a few examples of empirical research into MI. Table 3 shows some examples of management innovation operationalisation and measurement, which were conducted under the term "management innovation". 
Table 3. Operationalisation of management innovation applied in empirical studies in the last 10 years (2004-2014) - identified research results/cases

\begin{tabular}{|c|c|c|}
\hline Author/s & Dimensions of $\mathrm{MI}$ & Variables were measured using items \\
\hline $\begin{array}{l}\text { Mol \& Bir- } \\
\text { kinshaw } \\
(2009)\end{array}$ & $\begin{array}{l}1 / \text { the introduc- } \\
\text { tion of new mana- } \\
\text { gement practices }\end{array}$ & $\begin{array}{l}\text { 1/implementation of advanced management techniques } \\
\text { within your firm e.g. knowledge management, } \\
2 \text { / implementation of new or significantly changed } \\
\text { organisational structures e.g. diversification, } \\
\text { 3/ changing significantly your firm's marketing concepts/ } \\
\text { strategies e.g. marketing methods }\end{array}$ \\
\hline $\begin{array}{l}\text { Walker et al. } \\
\text { (2011) }\end{array}$ & $\begin{array}{l}1 \text { / information } \\
\text { technology } \\
2 / \text { administrative } \\
\text { procedures }\end{array}$ & $\begin{array}{l}\text { 1/ two statements concerning: } \\
\text { - new information technologies and } \\
\text { - new information systems for management purposes. } \\
\text { 2/ three statements concerning: } \\
\text { - new approaches to planning and budgeting services, } \\
\text { - new approaches to streamlining an organisation (e.g. } \\
\text { reengineering, TQM, quality management), } \\
\text { - new management procedures (e.g. new job descriptions, } \\
\text { new employee teams). }\end{array}$ \\
\hline $\begin{array}{l}\text { Vaccaro et } \\
\text { al. (2012) }\end{array}$ & $\begin{array}{l}\text { 1/ management } \\
\text { practices } \\
2 \text { / management } \\
\text { processes } \\
\text { 3/ organisational } \\
\text { structure }\end{array}$ & $\begin{array}{l}\text { Research tool - six items: } \\
1 / \text { two questions on changes in managers' activities - } \\
\text { establishing new principles or procedures; } \\
2 / \text { two questions on the ways to undertake action in an } \\
\text { organisation - changes in principles and work methods } \\
\text { (changes in management systems) and the issue of } \\
\text { remunerating employees; } \\
3 / \text { two questions on an organisational structure and the } \\
\text { way in which organisations approach communication and } \\
\text { information flow. }\end{array}$ \\
\hline $\begin{array}{l}\text { Hollen et al. } \\
\text { (2013) }\end{array}$ & $\begin{array}{l}1 / \text { setting objec- } \\
\text { tives } \\
2 / \text { motivating } \\
\text { employees; } \\
3 / \text { coordinating } \\
\text { activities; and } \\
\text { 4/ decision ma- } \\
\text { king. }\end{array}$ & $\begin{array}{l}\text { 1/ new-to-the-firm management activities associated with } \\
\text { setting objectives } \\
2 / \text { new-to-the-firm management activities associated with } \\
\text { motivating employees } \\
3 \text { / new-to-the-firm management activities associated with } \\
\text { coordinating activities } \\
\text { 4/ new-to-the-firm management activities associated with } \\
\text { decision making }\end{array}$ \\
\hline $\begin{array}{l}\text { Hecker } \\
\text { \& Ganter } \\
\text { (2013) }\end{array}$ & $\begin{array}{l}1 / \text { innovation in } \\
\text { the firm' s work- } \\
\text { place organisation } \\
2 / \text { innovation in } \\
\text { the firm's know- } \\
\text { ledge manage- } \\
\text { ment } \\
3 / \text { innovation in } \\
\text { the firm's external } \\
\text { relations }\end{array}$ & $\begin{array}{l}\text { 1/ new practices concerning the division and coordination } \\
\text { of labour, structuring activities, and distributing } \\
\text { responsibilities and decision making among employees. } \\
2 / \text { improvements in internal learning, knowledge sharing, } \\
\text { and organizational practices evolving from the use of } \\
\text { modern information and communication technology. } \\
3 \text { / new ways to organize collaboration with other firms and } \\
\text { public institutions }\end{array}$ \\
\hline
\end{tabular}




\section{METHODS AND RESULTS}

\section{Measurement of management innovation - our proposal}

The starting point for the development of the management innovation operationalisation, and its dimensions and measures, may already be mentioned in a definition of management innovation created by Birkinshaw, Hamel and Mol (2008). We assume that Ml embraces the management of an entire organisation or its significant areas and its effects go beyond a particular functional area (they are not restricted to one functional area, e.g. logistics or finance). Finally, we assert that this type of innovation can contribute to the increased technological innovativeness of an organisation and its improved performance (Volberda et al., 2013).

We assumed that management innovation is a multidimensional construct comprising of five dimensions, the choice of which is based on a number of modern theories concerning an organisation's innovativeness and the identified $\mathrm{MI}$ conceptualisations and operationalisations (Table 3). Accordingly, management innovation as a multidimensional construct comprises:

- a strategic dimension, which describes new development and competition strategies, including innovation, in particular technological (new products/services), new business models, new innovation sources;

- a structural dimension, determining a scope for the implementation of new solutions in an organisational structure, providing flexibility and adaptiveness to the conditions in which an organisation operates; new structural forms;

- employee motivation and development - the dimension concerning new methods, practices and programmes aimed at boosting employees' motivation and developing their skills and competencies (including their innovative activity);

- interorganisational relations and partnerships - the dimension describing the development and use of new forms of cooperation with different entities in the environment: suppliers, customers/ consumers, competitors, scientific institutions, etc.; the creation of open innovation models;

- an ICT dimension, which defines the scope and depth of changes implemented in the sphere of acquiring, collecting, processing and transferring information and knowledge; a new intra- and interorganisational communication tool.

Each dimension indicates the solutions that are new to an organisation and have not been used in its management so far. Below, the grounds for the choice of these dimensions are presented in more detail. 


\section{Strategic dimension}

A number of concepts concerning organisational innovativeness inspired the choice of the strategic dimension of management innovation and its operationalisation. Walker, Damanpour and Devece (2011) emphasised that management innovation was a new approach to the development of an organisation's strategy, the design of an organisational structure, the modification of management processes and employee motivation and remuneration. The $\mathrm{MI}$ strategic dimension draws heavily on the Organisational Innovativeness Construct, developed by Wang and Ahmed (2004). The authors distinguish five dimensions of innovativeness: product, process, market, and behavioural and strategic innovativeness. Their concept assumes that strategic innovativeness occurs when an organisation carries out a fundamental reconceptualisation of its core business, which, in turn, leads to a dramatically different way of operating. Wang and Ahmed (2004) argue that strategic innovativeness can be linked with the development of new competition strategies, creating value for an organisation.

The choice of the strategic dimension is also supported by the typology of management innovation presented by Damanpour and Aravind (2011). The authors point out that so far no universal typology of managerial innovation has been adopted and their proposal includes, among others, strategy and structure innovation (precisely speaking, they present innovation in an organisation's strategy vs. innovation in its structure). The results of studies indicate that radical changes in a structure follow radical changes in a strategy (but not the reverse). According to Damanpour and Aravind (2011), the distinction between structural and strategic innovations may contribute to a better understanding of managerial innovations in an organisation's conduct and performance. Dobni (2010), in turn, focuses on a strong link between a strategy and innovation and points out that, developing innovation competencies, acquiring innovation-related resources and incorporating innovation goals into a strategy should be considered crucial to an organisation's innovativeness. Innovative organisations need strategies that are externally oriented - concentrated on clients, customisation and enhanced quality. The inclusion of the strategic dimension in management innovation is also partly supported by the theoretical model of the innovativeness of small and medium enterprises (SMEs) proposed by Terziovski (2010). His model comprises independent constructs of innovation strategy, formal structure, customer and supplier relationships, innovation culture, and technological capabilities, which may affect the performance of firms (Terziovski, 2010). In his model of innovativeness, an innovation strategy is an independent variable, a key driver of innovation, positively affecting a firm's performance (2010). Akman and Yilmaz (2008) on the other hand, 
define an innovation strategy as a multidimensional construct, comprising, for example, an organisation's aggressive attitude towards emerging market opportunities, a capability to analyze and monitor the environment in search of opportunities, orientation towards the future, predicting future opportunities, planning innovation and others.

\section{Structural dimension}

The literature review reveals that a number of conceptualisations propose new organisational structures as a dimension of management innovation (Birkinshaw et al., 2008; Vaccaro et al., 2012; Walker et al., 2011). Organisational structures as a dimension of management innovation refer to how they align and harness the efforts of their members (Volberda et al., 2013). Changes in the organisational structure are perceived as the creation of new units/departments or positions (Elenkov \& Manev, 2005), as the shifts in the division of tasks and responsibilities (Vaccaro et al., 2012) or other changes in communication flows or rules and procedures within an organisation (Vaccaro et al., 2012). On the other hand Hecker and Ganter (2013) refer to the Oslo Manual methodology for researching management innovation and they embrace innovations concerning workplace organisation, defined as new practices involving the division and coordination of work, the structuralisation of operations, the delegation of responsibilities and decisionmaking competencies to employees. In another approach, Hollen, Van Den Bosch and Volberda (2013) also account for coordinating activities, defining this dimension of management innovation as new-to-the-firm management activities associated with coordinating activities.

\section{Employee motivation and development dimension}

Innovations in organisations predominantly rely on the activity of their employees, both R\&D specialists and other staff. It is commonly viewed that it is innovative leaders who possess the skills that foster the commitment of companies and individuals to be innovative and to innovate. Innovative managers are able to motivate the internal workforce to be innovative and to discover new products, services, processes or ideas (Cavagnoli, 2011). The importance of this concept means that many scholars interested in management innovation research, recognise the necessity to seek new solutions in the area of employee motivation and development, both in order to increase the firm's effectiveness and find new sources of competitive advantage. In their four-dimensional model of management innovation, Mol and Birkinshaw (2009) propose that management practices embrace such 
components as setting objectives and associated procedures, arranging tasks and functions, and developing talent.

In their studies on the contribution of top management to organisational innovation, Elenkov and Manev (2005) classify new programmes for human resource development as organisational innovations, whereas the conceptualisation proposed by Hollen, Van Den Bosch and Volberda (2013) incorporates four management activities, including new-to-the-firm management activities associated with motivating employees, which draw on the concepts developed by Birkinshaw and Goddard (2009) and Birkinshaw (2010).

Finally, in the conceptualisation proposed by Vaccaro et al. (2012), the dimension of management processes in management innovation is measured with two items, which relate to how work is performed and include changes articulated in routines that govern the work of people as well as how compensation is set up. This may be illustrated by changes in management systems or changes in what is expected of people, which outcomes and behaviour are rewarded and which are not, which relate to the way people are compensated.

\section{Dimension of interorganisational relations (partnerships)}

From the perspective of building the innovativeness of an organisation, the role and significance of effective forms and types of interorganisational relations are universally recognised. Birkinshaw, Hamel and Mol (2008) explicitly conceptualise management innovation as taking place between interacting organisations; also other scholars identify the organisationalcooperation mode as a particularly prominent one for non-technological innovation (Meuer, 2013). It can be assumed that building new, open innovation models including organisations in a firm's environment (customers, suppliers, scientific institutions, etc.) is an important manifestation of $\mathrm{Ml}$. Meuer (2013) argues that four distinct archetypes of inter-firm relations lead to the implementation of MI.

In his methodology for researching a firm's innovativeness, Terziovski (2010) also recognises the dimension of creating new configurations of interorganisational relations and building new forms of cooperation between a firm and other entities in its environment. His innovation constructs (i.e. independent constructs) contain "customer and supplier relationships" (Terziovski, 2010). Hecker and Ganter, drawing on the Oslo Manual methodology (2008), suggest that innovations in external relations with entities in the environment should be operationalised as new ways of organizing cooperation with other firms and public institutions (Hecker 
\& Ganter, 2013; Camison \& Villar-Lopez, 2014). The role of different forms of cooperation between an organisation and other external entities in the innovation process is also recognised by Lee (2009), who indicates differences in how advanced the relations existing between an organisation and its customers, suppliers and other entities are. Finally, the development of global innovation networks, considered in terms of their structural aspects and knowledge management, also play a significant role (Horn \& Brem, 2012).

\section{ICT dimension}

Numerous studies confirm the important role of modern information and communication technologies (ICT) not only in management processes, but also in speeding up innovation in several sectors and facilitating communication over long distances, which contributes to transformations in entire industries and, as a result, advances the globalisation of the world economy (Lundvall \& Nielsen, 2007).

The review of literature on management innovation and its operationalisations indicate that many scholars and research teams recognise the IT dimension (Walker et al., 2011; Shieh \& Wang, 2005). Elenkov and Manev (2005) also include this dimension as new management information systems in their considerations on the influence of top management (leadership) on organisational innovation (Shieh \& Wang, 2005).

\section{The proposal of management innovation measurement and its empirical validation}

Based on the analysis of the management innovation operationalisations (or organisational innovation), presented in literature, and the research tools that have been used so far, we developed 17 items broken down into the five dimensions (Table 4). The assessment of these items should reflect a level/scope of management innovations, generated and implemented in a particular enterprise. Accordingly, the following way of measuring management innovations is proposed:

1) the items describe the scope of meaningful changes/new solutions implemented in the area of management within the last three years (not used so far);

2) each item is assessed on a 7-point Likert scale (7 - Strongly agree to 1 Strongly disagree).

The validation of the management innovation measurement instrument was conducted in enterprises based throughout Poland in 2014. In 8 provinces, a random sample of firms was generated from companies registered in the Central Statistical Office database. While in terms of 8 provinces the screening 
criterion was the number of registered enterprises, choice of enterprises was random, nonetheless proportionate. A total of 301 questionnaires were returned for an overall response rate of $30 \%$. A variety of industries were represented including manufacturers, trade, services and mixed companies. Top or middle managers in those enterprises (who expressed their consent to participate in the survey) received the questionnaire directly from a pollster and answered it in his/her presence. This is consistent with the approach suggested by Selltiz, Wrightsman and Cook (1976) and Nunnally (1978) that the subjects used should be those whom the instrument was intended. The empirical validation of the measurement tool was in Polish, that is, the questionnaire was distributed to managers in their native language.

The first stage of the statistical analysis involved testing the reliability of the tool applied. For this purpose the internal consistency analysis with the use of Cronbach's alpha and the exploratory factor analysis was conducted. Table 4 presents the values of Cronbach's alpha for five dimensions of management innovation and for particular items.

Table 4. Cronbach's alpha for particular items and management innovation dimension

\begin{tabular}{ll}
\hline Dimensions & $\begin{array}{l}\text { Cronbach's } \\
\text { alpha }\end{array}$ \\
\hline $\begin{array}{l}\text { Strategic dimension } \\
\text { In the last three years in our firm we have implemented significant changes: }\end{array}$ & $\mathbf{0 . 8 3}$ \\
\hline $\begin{array}{l}\text { 1. in the competition strategy, orienting it towards new markets and/or opening } \\
\text { new market space }\end{array}$ & 0.787 \\
$\begin{array}{l}\text { 2. in the corporate development strategy so that innovations could be an } \\
\text { important/main source of competitive advantage }\end{array}$ & 0.757 \\
$\begin{array}{l}\text { 3. in the ways of monitoring the environment in order to seize opportunities for } \\
\text { developing (and/or adapting) innovations (product, technological, marketing) }\end{array}$ & 0.759 \\
$\begin{array}{l}\text { 4. new management methods/systems facilitating the implementation of } \\
\text { strategies (e.g. Strategic Score Card, TQM) }\end{array}$ & 0.830 \\
\hline $\begin{array}{l}\text { Structural dimension } \\
\text { In the last three years in our firm we have introduced: }\end{array}$ & $\mathbf{0 . 8 7}$ \\
\hline $\begin{array}{l}\text { 5. meaningful/radical changes in principles and procedures } \\
\text { 6. changes in the scope of tasks and responsibilities of our employees and the }\end{array}$ & 0.818 \\
$\begin{array}{l}\text { ways of coordinating assignments } \\
\text { 7. new organisational solutions in the communication systems in divisions } \\
\text { (branches, subsidiaries) and between them }\end{array}$ & 0.817 \\
\begin{tabular}{l} 
8. new forms of organisational structures, new branches/units/positions \\
\hline $\begin{array}{l}\text { Employee motivation and development dimension } \\
\text { We have introduced entirely new and considerably modified }\end{array}$
\end{tabular} & 0.853 \\
\hline $\begin{array}{l}\text { 9. remuneration systems promoting employee innovative behaviour and } \\
\text { increased productivity }\end{array}$ & 0.79 \\
$\begin{array}{l}\text { 10. systems/methods for task planning and employee/team performance } \\
\text { control }\end{array}$ & 0.733 \\
$\begin{array}{l}\text { 11. practices/programmes aiming at human resource development (e.g. } \\
\text { promotion, training, mentoring, coaching systems) }\end{array}$ & 0.740 \\
\hline & 0.677 \\
\hline
\end{tabular}




\begin{tabular}{ll}
\hline $\begin{array}{l}\text { Interorganisational relations (partnership) dimension } \\
\text { In the last three years in our firm we have created }\end{array}$ & $\mathbf{0 . 8 2}$ \\
\hline $\begin{array}{l}\text { 12. unique relations with customers aiming to identify their needs, respond to } \\
\text { these needs more quickly and retain customer loyalty }\end{array}$ & 0.714 \\
$\begin{array}{l}\text { 13. new forms of cooperation with suppliers in order to streamline operational } \\
\text { efficiency, develop new technologies, etc. }\end{array}$ & 0.638 \\
$\begin{array}{l}\text { 14. forms of cooperation with our competitors in order to reduce costs of radical } \\
\text { innovations }+\end{array}$ & \\
$\begin{array}{l}\text { 15. new forms of cooperation with experts/consultants, R\&D centres, higher } \\
\text { schools, in order to implement innovations and seek solutions to problems † }\end{array}$ & 0.751 \\
\hline $\begin{array}{l}\text { ICT dimension } \\
\text { In the last three years in our firm we have implemented new or heavily } \\
\text { modified }\end{array}$ & $\mathbf{0 . 7 7}$ \\
$\begin{array}{l}\text { 16. IT systems supporting managerial decision-making processes } \\
\text { 17. IT systems and other communication tools or practices in order to } \\
\text { acquire and collect information and knowledge and disseminate them among } \\
\text { employees (e.g. Intranet, knowledge bases) }\end{array}$ & 0.697 \\
\hline
\end{tabular}

The next step involved the exploratory factor analysis, which allows for the reduction of a large number of variables to a few mutually uncorrelated factors or principal components. Prior to the factor analysis, the adequacy of the selected variables was tested with the Kaiser-Meyer-Olkin statistic. The $\mathrm{K}-\mathrm{M}-\mathrm{O}$ analysis yielded the value of 0.970 , allowing the application of the exploratory factor analysis. Table 5 presents the values of statistics for the factor analysis.

Table 5. Values of statistics for the factor analysis

\begin{tabular}{lllll}
\hline $\begin{array}{l}\text { Factor/ } \\
\text { dimension }\end{array}$ & Own value & $\begin{array}{l}\text { Variance } \\
\text { explanation }\end{array}$ & $\begin{array}{l}\text { Cumulative own } \\
\text { value }\end{array}$ & $\begin{array}{l}\text { Variance } \\
\text { explanation }\end{array}$ \\
\hline 1 & 7.225 & 48.168 & 7.225 & 48.168 \\
2 & 1.343 & 8.952 & 1.343 & 57.120 \\
3 & 1.206 & 8.043 & 1.206 & 65.163 \\
4 & 0.874 & 5.827 & 0.874 & 70.990 \\
5 & 0.703 & 4.687 & 0.703 & 75.677 \\
\hline
\end{tabular}

In order to determine the number of factors Jolliffe's criterion was used, which allowed us to distinguish five factors. This corresponds with the five dimensions of management innovation assumed in the model. However, relying on results obtained from factor analysis, we decided to remove two items (14 and 15) from Dimension 4, due to a lack of consistency shown within the assumed dimension. Based on the cumulative percentage of variance explained by the factors we show that the model consisting of the five constructed dimensions of management innovation accounts for $75.7 \%$ of the total variability in this aspect. 


\section{DISCUSSION AND CONCLUSIONS}

The objective of our study was to develop a management innovation concept taking into account its five dimensions, which could better explain the nature of this kind of innovation, as so far it has been studied a lot less than technological innovation. The literature review confirms that the theme of innovation in management is relatively poorly researched and innovations of this type are not represented enough in the existing innovation theories/ models. A consistent management innovation concept that would explain the sources of management innovation, its antecedents and effects, has yet to be developed. This gap in knowledge is observed by a number of scholars (Vaccaro et al., 2012; Birkinshaw et al., 2008; Volberda et al., 2013). Another gap, which we aimed to fill, was the lack of a management innovation measurement tool. We developed a five-dimensional Ml construct, which was tested for reliability and adequacy. Statistical methods verified its high reliability measured with Cronbach's alpha and validated the constructed dimensions. The tool consists of 15 items, which can be used to measure management innovation in business enterprises and other organisations (e.g. public institutions). Our management innovation measurement instrument is much more complex than those used by others (summarized in the Table 3 ) and includes those aspects of the MI that have been subject of various studies, however in dispersion. In our opinion, the proposed instrument is therefore more accurate and integrates those dimensions of management innovation, which have been suggested by other researchers, but never before in such a configuration.

Our study also shows that the classification in the Oslo Manual (2005) could be expanded to embrace the fifth type of innovation - management innovation. This would require the re-definition of organisational innovation (which could, for example, concern new solutions in the area of particular functions: logistics, marketing, etc.) and management innovation (as new solutions in the management of an entire organisation). To conclude, further research into this field can be considered as fully justified.

\section{Limitations}

The presented research results have their limitations. The management innovation measurement scale draws only on the exploratory factor analysis and the subjective choice of Jolliffe's criterion as a criterion for factor analysis. Moreover, the way of measuring $\mathrm{MI}$ is based on the subjective assessment made by top managers (self-reported survey data), who express their opinion on the implementation of significant/radical changes in their firm's management within the last three years. Basically, they have to 
evaluate their own innovative activity, which may be problematic due to a natural tendency to overestimate our own actions. Another limitation of our research concerning literature review is a selective choice of papers inevitably authors are doomed to make choices, which is always at risk of missing an important source. The next limitation might be the fact that our study focuses on the Polish context only, as a lack of studies on this issue in our country was observed. Since there has been little empirical research on management innovation practices reported in the extant literature, it is difficult to know how industry classification or industry size might bias the results.

\section{Future research}

Our research results confirm that the measurement of innovation in general (Adams et al., 2006), and the measurement of management innovation in particular, is complex and difficult. However, it is essential in evaluating the effectiveness of innovation activity. What is more, the presented MI model and its measurement scale, encourage further research into links between management innovation and a firm's performance, technological innovation or organisational culture, as well as focusing on the moderator effect of some variables on the culture-innovation relationship. The latter is considered by researchers to be a particularly important factor influencing the level of innovativeness in enterprises (Dobni, 2008; Dobni, 2010; Choudhary, 2014). The management innovation field, in our opinion, should be recognised as an important factor in stimulating innovativeness in enterprises while they aim to boost their competitive advantage. We also agree with the opinion expressed by many researchers that "innovation is an essential condition of economic progress and a critical element in the competitive struggle of both enterprises and nation state" (Beaver \& Prince, 2002; Brem, 2011).

Obviously, our study should encourage further research into improvements and modifications of this tool for measuring management innovation. Generally speaking, future studies should address the abovementioned limitations and could include testing on another sample in Poland (i.e. replication after a given period of time) or testing on the same sample in different transition economies. The latter is especially important due to the issue of cultural bias and a generally low level of innovation awareness in Poland. Indicating future research areas concerning management innovation, it should be born in mind that management innovation should be analysed by taking into account its dynamic prospects, offered mainly by complexity theories (Amagoh, 2008). 


\section{Managerial implications}

Our literature review and research results lead to a number of conclusions useful for managers and business practice. First of all, managers need to bear in mind the importance of various types of innovation, besides technological innovation, as well as the necessity to create an adequate organisational culture, which may play a vital role in advancing organisational innovativeness. Furthermore, the presented management innovation model and its measurement scale may be used in order to diagnose the level of management innovation and to assess its effectiveness, costs and benefits. The measurement instrument can be used by practitioners - managers in charge of an enterprise - not only to assess their own innovative activity, but also to look for new sources of competitive advantage.

In conclusion, it should be emphasized that in the past, issues related to technological innovation significantly dominated research on innovation in organisations. Recent changes in global markets and the necessity to seek new sources of competitive advantage justify paying increased attention to management innovation. In response to this challenge we made an attempt at conceptualizing management innovation and developing a scale for its measurement. The proposed five-dimension management innovation model can be used to measure the scope of management innovation in further research and develop the knowledge about links between $\mathrm{MI}$ and an organisation's performance or its impact on technological innovativeness. Previous research results regarding these relationships, although promising (Kraus et al., 2012; Hecker \& Ganter, 2013), do not provide a definite answer concerning relations between variables, which additionally justifies further studies using the more sophisticated MI measurement proposed by us. It can also be used as a diagnostic tool to determine the innovativeness of a firm's management and compare it with other organisations, for example, in a given industry.

\section{Acknowledgements}

The paper is a result of a research project financed by the National Science Centre: "The impact of management innovation on technological innovation and business performance" (Wpływ innowacji zarządczych na innowacyjność technologiczną i wyniki przedsiębiorstw), NCN nr 2012/07/B/HS4/00314.

\section{References}

Adams, R., Bessant, J., \& Phelps, R. (2006). Innovation management measurement: A review. International Journal of Management Reviews, 8(1), 21-47. 
Ahn-Sook, H. (2004). Integrating Technology, Marketing, and Management Innovation. Research- Technology Management, 47(4), 23-35.

Akman, G., \& Cengiz, Y. (2008). Innovative Capability. Innovation Strategy and Market Orientation: An empirical Analysis in Turkish Software Industry. International Journal of Innovation management, 12(1), 77-78.

Amagoh, F. (2008). Perspectives on Organizational Change: Systems and Complexity Theories. Public Sector Innovation Journal, 13(3), 1-14.

Bantel, K. A., \& Jackson, S. E. (1989). Top management and innovations in banking - does the composition of the top team make a difference?. Strategic Management Journal, 10(1), 107-124.

Beaver, G., \& Prince, G. (2002). Innovation, entrepreneurship and competitive advantage in the entrepreneurial venture. Journal of Small Business and Enterprise Development, 9(1), 28-37.

Birkinshaw, J. (2010). Reinventing management. Chichester: John Wiley \& Sons Ltd.

Birkinshaw, J., \& Goddard, J. (2009). What is your Management Model?. Sloan Management Review, 50(2), 81-90.

Birkinshaw, J., \& Mol, M. M. (2006). How Management Innovation Happens, MIT Sloan Management Review, 47(4), 81-88.

Birkinshaw, J., Hamel, G., \& Mol, M. M. (2005). Management innovation. Advanced Institute of Management Research. Retrieved from http:// www.managingpeoplebook.com/userimages/aim_management_ innovation.pdf

Birkinshaw, J., Hamel, G., \& Mol, M. M. (2008). Management innovation. Academy of Management Review, 33(4), 825-845.

Brem, A. (2011). Linking innovation and entrepreneurship-literature overview and introduction of a process-oriented framework. International Journal of Entrepreneurship and Innovation Management, 14(1), 6-35.

Camison, C., \& Villar-Lopez, A. (2014). Organizational innovation as an enabler of technological innovation capabilities and firm performance. Journal of Business Research, 67, 2891-2902.

Cavagnoli, D. (2011). A conceptual framework for innovation: an application to human resource management policies in Australia. InnovationManagement Policy \& Practice, 13(1), 111-125.

Chandler, A.D. (1962). Strategy and structure: Chapters in the history of the industrial enterprise. MIT, Press, Cambridge.

Cho, H. J., \& Pucik, V. (2005). Relationship between innovativeness, quality, growth, profitability, and market value. Strategic Management Journal, 26(6), 555-575.

Choudhary, A. (2014). Four critical traits of innovative organizations. Journal of Organizational Culture, Communications and Conflict, 18(2), 45-58.

Crossan, M. M., \& Apaydin, M. (2010). A Multi-Dimensional Framework of Organizational Innovation: A Systematic Review of the Literature. Journal of Management Studies, 47(6), 1154- 1191. 
Damanpour, F., \& Evan, W. M. (1984). Organizational innovation and performance: The problem of organizational lag. Administrative Science Quarterly, 29(3), 392-409.

Damanpour, F. (1996). Organizational complexity and innovation: Developing and testing multiple contingency models. Management Science, 42(5), 693-713.

Damanpour, F., \& Aravind, D. (2011). Managerial Innovation: Conceptions, Processes, and Antecedents. Management and Organization Review, 8(2), 423-454.

Danneels, E., Kleinschmidt, E. J., \& Cooper, R. G. (2000). Product innovativeness from the firm's perspective: Its dimensions and their impact on project selection and performance, (Rev 1/2000), Institute for the Study of Business Markets, The Pennsylvania State University, ISBM Report 42000.

DG Enterprise and Industry. (2009). Innobarometer. European Commission, Brussels.

Dobni, B.C. (2008). Measuring innovation culture in Organizations. The development of a generalized innovation culture construct using exploratory factor analysis. European Journal of Innovation Management, 11(4), 539- 559.

Dobni, B.C. (2010). The Relationship Between an Innovation Orientation and Competitive Strategy. International Journal of Innovation Management, 14(2), 331-357.

Edquist, Ch., Hommen, L., \& McKelvey, M. (2001). Innovation and employment: Process versus product innovation. Cheltenham: Edward Elgar.

Eisenhardt, K., \& Martin, J. A. (2000). Dynamic capabilities: What are they?. Strategic Management Journal, 21(10/11), 1105-1121.

Elenkov, D. S., \& Manev, I. M. (2005). Top Management Leadership and Influence on Innovation: The Role of Sociocultural Context. Journal of Management, 31(3), 381-402.

Gallego, J., Rubalcaba, L., \& Hipp Ch. (2012). Organizational innovation in small European firms: A multidimensional approach. International Small Business Journal, 2, 1-17.

Garcia, R., \& Calantone, R. (2002). A critical look at technological innovation typology and innovativeness terminology: a literature review. The Journal of Product Innovation Management, 19, 110-132.

Gholamreza, R., Damirchi, G. V., \& Seyyedi, M.H. (2011). Management Behavior and Organizational Innovation. Interdisciplinary Journal of Contemporary Research in Business, 3(3), 78-95.

Gosselin, M. (1997). The effect of strategy and organizational structure on the adoption of Activity- Based Costing Accounting. Organizations and Society, 22(2), 105-122.

Hamel, G. (2006). The Why, What, And how of Management Innovation. Harvard Business Review, 84(2), 72-83. 
Hecker, A., \& Ganter, A. (2013). The Influence of Product Market Competition on Technological and Management Innovation: Firm-Level Evidence from a Large-Scale Survey. European Management Review, 10(1), 1733.

Hilmi, M. F., Ramayah, T., Mustapha, Y., \& Pawanchik, S. (2010). Product and process innovativeness: Evidence from Malaysian SMEs. European Journal of Social Science, 16(4), 556- 565.

Hollen, R. M. A., Van Den Bosch, F. A. J., \& Volberda, H. W. (2013). The role of management innovation in enabling technological process innovation: an inter-organizational perspective. European Management Review, 10, 35-50.

Horn, Ch., \& Brem, A. (2012). Strategic directions on innovation management - a conceptual framework. Management Research Review, 36(10), 939954.

Kraśnicka, T., Głód, W., \& Wronka, M. (2014). Pojecie, determinanty i znaczenie innowacji zarzadczych (management innovation) - stan badań nad zjawiskiem. In J. Brzoska, J. Pyka (Eds.). Zeszyty Naukowe Politechniki Slaskiej, Organizacja i Zarzadzanie, z. 73, Wydawnictwo Politechniki Slaskiej, Gliwice, 333-349.

Kraus, S., Pohjola, M., \& Koponen, A. (2012). Innovation in family firms: an empirical analysis linking organizational and managerial innovation to corporate success. Review of Managerial Science, 6, 265-286.

Lam, A. (2004). Organizational innovation. In J. Fagerberg, D.C. Mowery and R. R. Nelson (Eds.). The Oxford handbook of innovation, Oxford University Press, New York.

Lee, J. (2008). Effects of leadership and leader-member exchange on Innovativeness. Journal of Managerial Psychology, 23(6), 670-687.

Lee, L., \& Kam, W. P. (2009). Firms Innovative Performance: The mediating Role of Innovative Collaborations. American Academy of Management Conference, Chicago.

Lundvall, B.Å., \& Nielsen, P. (2007). Knowledge management and innovation performance. International Journal of Manpower, 28(3/4), 22-37.

Martins, E., \& Terblanche, F. (2009). Building organizational culture that stimulates creativity and innovation. European Journal of Innovation Management, 6(1), 64-74.

Mayle, D. (2002). Managing innovation and change. London, UK: Sage.

Meuer, J. (2013). Archetypes of Inter-firm Relations in the Implementation of Management Innovation: A Set-theoretic Study in China's Biopharmaceutical Industry. Organization Studies, 35(1), 121-145.

Mol, M. J., \& Birkinshaw, J. (2009). The sources of management innovation: When firms introduce new management practices. Journal of Business Research, 62(12), 1269-1280.

Mol, M. J., \& Birkinshaw, J. (2012). Relating management innovation to product and process innovation: Private rents versus public gains. In 
T. S. Pitsis, A.Simpson and E. Dehlin (Eds.). Handbook of organizational and managerial innovation. Cheltenham, Edward Elgar.

Mothe, C., \& Thi, T. U. N. (2010). The link between non-technological innovations and technological innovation. European Journal of Innovation Management, 13(3), 313-332.

Nelson, R. R., \& Sampat, B. N. (2001). Making Sense of Institutions as a Factor Shaping Economic Performance. Journal of Economic Behavior \& Organization, 44(1), 31-54.

Nowacki, R. (Ed.). (2010). Innowacyjnosc w zarzadzaniu a konkurencyjnosc przedsiebiorstwa. Difin, Warszawa.

Nunnally, J.C. (1978). Psychometric Theory (2nd ed.). McGraw-Hill Book Company, New York, NY.

OECD and Eurostat. (2005). Oslo Manual. Guidelines for Collecting and Interpreting Innovation.

Perello-Marin, M. R., Marin-Garcia, J. A., \& Marcos-Cuevas J. (2013). Towards a path dependence approach to study management innovation. Management Decision, 51(5), 1037-1046.

Pichlak, M. (2012). Uwarunkowania innowacyjnosci organizacji. Studium teoretyczne i wyniki badań empirycznych, Difin, Warszawa.

Podsakoff, P. M., Mackenzie, S.B., Bachrach, D.G., \& Podsakoff, N.P. (2005). The influence of management journals in the 1980s and 1990s. Strategic Management Journal, 26(5), 473-488.

Prahalad, C. K., \& Krishnan, M.S. (2008). The New Age Of Innovation: Driving Co-Created Value Through Global Networks, McGraw-Hill.

Rahimi, G., Damirchi, Q. V., \& Seyyedi, M. H. (2011). Management Behavior and Organizational Innovation. Interdisciplinary Journal of Contemporary Research in Business, 3(6), 874-889.

Ravichandran ,T. (2000). Swiftness and intensity of administrative innovation adoption: An empirical study of TQM in information system. Decision Sciences, 31(3), 691-724.

Salavou, H. (2004). The concept of innovativeness: should we need to focus?. European Journal of Innovation Management, 7(1), 33-44.

Sanidas, E. (2005). Organizational innovations and economic growth: Organosis and growth of firms, sectors, and countries, Cheltenham: Edward Elgar.

Santos-Vijande, M. L., \& Álvarez-González, L. I. (2007). Innovativeness and organizational innovation in total quality oriented firms: The moderating role of market turbulence. Technovation, 27(9), 514-532.

Selltiz, C., Wrightsman, L.S., \& Cook, S.W. (1976). Research Methods in Social Relations. (3rd ed.). Holt, Rinehart, and Winston, New York, NY.

Shieh, Ch.-J., \& Wang, I-M. (2010). A study of relationships between corporate core competence, management innovation and corporate culture. International Journal of Organizational Innovation, 2(3), 390-411.

Sundbo, J., Gallina, A. Serin, G., \& Davis, J. (Eds.). (2006). Contemporary Management of Innovation. Palgrave MacMillan, Great Britain. 
Tanninen, K., Jantunen, A., \& Saksa, J. M. (2008). Adoption of administrative innovation within organization- An empirical study of TQM metamorphosis. International Journal of Innovation and Technology Management, 5(3), 321-340.

Terziovski, M. (2010). Innovation practice and its performance implications in small and medium enterprises (SMEs) in manufacturing sector: a resources-based view. Strategic Management Journal, 31, 892-902.

Timmerman, J. C. (2009). A Systematic Approach for Making Innovation a Core Competency. The Journal for Quality and Participation, 31(4), 4-11.

Tranfield, D., Denyer, D., \& Smart, P. (2003). Towards a methodology for developing evidence- informed management knowledge by means of systematic review. British Journal of Management, 14(3), 207-222.

Vaccaro, I. G., Jansen, J. J.P, Van Den Bosch F. A. J., \& Volberda, H.W. (2012). Management Innovation and Leadership: The Moderating Role of Organizational Size. Journal of Management Studies, 49(1), 28-51.

Volberda, H. W., Van Den Bosch F. A. J., \& Heij C. V. (2013). Management Innovation: Management as Fertile Ground for Innovation. European Management Review, 10(1), 1-15.

Walker, R. M., Damanpour, F., \& Devece, C. A. (2011). Management Innovation and Organizational Performance: The Mediating Effect of Performance Management. Journal of Public Administration Research and Theory, 21(2), 367-386.

Wang, C. L., \& Ahmed, P.K. (2004). The development and validation of the organizational innovativeness construct using confirmatory factor analysis. European Journal of Innovation Management, 7(4), 303-313.

Wickham, P. A. (2006). Strategic Entrepreneurship (4th ed.). Prentice Hall Harlow, England.

Williamson, O. E. (1975). Markets and hierarchies. New York, The Free Press. Wood, R. C. (2007). How strategic innovation really gets started. Strategy \& Leadership, 35(1), 21-29.

\section{Abstract (in Polish)}

Celem artykułu było wyjaśnienie istoty innowacji zarzqdczych i zaproponowanie narzędzia ich pomiaru. W artykule dokonano przegladu kluczowych pozycji czasopism naukowych z ostatnich 20 lat, dotyczqcych tematyki innowacji zarzqdczych. Krytycznej ocenie poddano zwłaszcza definicje, proponowane wymiary innowacji zarzqdczych, oraz stosowane skale ich pomiaru. Na tej podstawie zaproponowano wielowymiarowy konstrukt innowacji zarzqdczych i stworzono autorskie narzędzie służqce do badania/mierzenia innowacji zarzqdczych. Uwzględniono w nim następujqce wymiary: strategiczny, strukturalny, wymiar motywowania i rozwoju pracowników, wymiar więzi międzyorganizacyjnych oraz wymiar ICT. Narzędzie zostało poddane weryfikacji statystycznej z wykorzystaniem analizy zgodności wewnętrznej (test alfa Cronbacha) oraz analizy czynnikowej - w oparciu o badania przeprowadzone w 301 polskich przedsiębiorstwach. Uzyskano zadawalajqce wyniki, pozwalające na podjęcie badań 
tego typu innowacji. Przeprowadzone studia przyczynity się do rozwoju wiedzy na temat natury innowacji zarzqdczych. Ponadto $w$ artykule przedstawiono konkretne implikacje teoretyczne i praktyczne, w szczególności podkreślajqc, że zaproponowany pięciowymiarowy model innowacji zarzq̨dczych może być wykorzystany do pomiaru natężenia tych innowacji oraz w dalszych badaniach zwiq̨zków pomiędzy innowacjami zarzq̨dczymi a wynikami przedsiębiorstw czy ich innowacyjnościq technologicznq. Przeprowadzone badania pozwolity także na wskazanie dalszych kierunków badań, dostarczajqc zainteresowanym tq problematykq bogatej wiedzy o innowacjach zarzqdozych.

Słowa kluczowe: innowacje, innowacje zarzqdcze, pomiar.

\section{Biographical notes}

Teresa Kraśnicka is an Associate Professor in the University of Economics in Katowice. She is a head of the Department of Entrepreneurship and Management Innovation. She gained her PhD at the University of Economics in Katowice. Her current research interests focus on: entrepreneurship, innovation, and management innovation.

Wojciech Głód holds a Ph.D. in Management from the University of Economics in Katowice where he currently works as Assistant Professor in the Department of Entrepreneurship and Management Innovation. His research interest is entrepreneurship and innovation focusing on the health care sector.

Martyna Wronka-Pośpiech holds a Ph.D. in Management from the University of Economics in Katowice where she currently works as Assistant Professor in the Department of Entrepreneurship and Management Innovation. Her research is focused on entrepreneurship, innovation and strategic management in the social and public sectors. 
